\title{
BMJ Open Prenatal and neonatal factors for the development of childhood visual impairment in primary and middle school students: a cross-sectional survey in Guangzhou, China
}

Bolan Yu (D) , ${ }^{1,2}$ Lijuan Dai, ${ }^{2}$ Juanjuan Chen, ${ }^{2}$ Wen Sun, ${ }^{2}$ Jingsi Chen, ${ }^{2}$ Lili Du, ${ }^{2}$ Nali Deng, ${ }^{3}$ Dunjin Chen ${ }^{2,4}$

To cite: Yu B, Dai L, Chen J, et al. Prenatal and neonatal factors for the development of childhood visual impairment in primary and middle school students: a cross-sectional survey in Guangzhou, China. BMJ Open 2020;10:e032721. doi:10.1136/ bmjopen-2019-032721

- Prepublication history for this paper is available online. To view these files, please visit the journal online (http://dx.doi. org/10.1136/bmjopen-2019032721).

Received 03 July 2019

Revised 20 July 2020

Accepted 04 August 2020
Check for updates

(C) Author(s) (or their employer(s)) 2020. Re-use permitted under CC BY-NC. No commercial re-use. See rights and permissions. Published by BMJ.

For numbered affiliations see end of article.

Correspondence to Dr Bolan Yu; 1692299632@qq.com and Dr Dunjin Chen; gzdrchen@gzhmc.edu.cn

\section{ABSTRACT}

Objectives In this cross-sectional survey, we sought to determine the prevalence of and the influence of prenatal and neonatal factors on childhood visual impairment without correction (VIUC) in a paediatric population from Guangzhou, China.

Setting The health survey covered 11 administrative districts in Guangzhou, including 991 schools.

Participants All of the primary and middle school students in Guangzhou were invited to complete an online questionnaire with the help of their parents. The results of physical examinations were reported by school medical departments. The results of the questionnaire were collected by the researchers. In total, 253301 questionnaires were collected.

Primary outcome measures The students' uncorrected visual acuity (UCVA) was examined by trained optometrists by standard logarithmic visual acuity charts. VIUC was defined by UCVA (of the better eye) (UCVA $<6 / 12$ ) with three levels: light VIUC (UCVA $\geq 6 / 18$ to $<6 / 12$ ), mild VIUC (UCVA $\geq 6 / 60$ to $<6 / 18$ ) and severe VIUC (UCVA $<6 / 60$ ). Results A total of 39768 individuals (15.7\%) had VIUC, and the rate was much higher among grade 10 to 12 students $(51.4 \%)$ than among grade 1 to 6 students $(6.71 \%)$. The following factors were significantly associated with an increased risk of VIUC: female gender, high birth weight, formula feeding, not having siblings, higher level of parents' education, parental myopia, much homework time and little outdoor activity. Delivery mode was not associated with the risk of VIUC.

Conclusions This study validates known major prenatal/ genetic, perinatal and postnatal factors for childhood VIUC. In conclusion, prenatal and perinatal factors can affect the onset of childhood VIUC, but parental myopia and postnatal factors are the main factors.

\section{INTRODUCTION}

Visual impairment is highly prevalent in school students, and myopia-related visual impairment without correction (VIUC) accounts for over $90 \%$ of the cases in China. Myopia is caused by an inconsistency between
Strengths and limitations of this study

- A retrospective study conducted using 253301 completed surveys in the Guangzhou area of Southern China.

- Collection and analysis of both prenatal and environmental factors associated with vision impairment without correction.

- Selection bias, recall bias and reporter bias are unavoidable as the survey was based on voluntary participation.

the eye's refractive power and the length of the eye axis. Two clinical types exist. In refractive myopia, the axial length is normal, but the refractive power of the cornea or lens is too strong, while in axial myopia, the refractive power of the lens is normal, but the axial length is too long. ${ }^{2}$ Although myopia is not a life-threatening disease, the WHO recognises it as a major cause of further visual impairment if not fully corrected. ${ }^{3}$ At present, the high prevalence of myopia has become a serious public health problem in East Asia. In China specifically, the prevalence of myopia in high school students ranges from $43.0 \%$ to $78.4 \%$.

Myopia is aetiologically heterogeneous and is believed to be driven by numerous environmental factors and genetic variations, with onset beginning in the preschool years. Environmental factors such as outdoor activity are associated with myopia inception and development. ${ }^{4}$ Increasing outdoor time thus represents an important environmental factor that can protect young children from myopia, as supported by numerous studies. ${ }^{5-7}$ The protective effects of outdoor activity may be due to the high light intensity outdoors, the chromaticity of daylight or increased vitamin 
D levels. ${ }^{89}$ A number of studies have separately shown that parental myopia is an important risk factor for myopia in children, due to the inheritance of myopia susceptibility genes or a shared myopia-driving environment. ${ }^{10-12}$

According to the developmental origins of health and disease theory, the development of childhood diseases may be affected by factors in prenatal life. ${ }^{13}$ Several epidemiological studies have shown that caesarean delivery and preterm birth increase the risk of childhood myopia. ${ }^{14-17}$ For example, preterm birth may affect ocular development or later emmetropisation, and it may affect the development of the refractive status through a more complicated mechanism. ${ }^{18-22}$ In addition, breast feeding in early life may stimulate ocular development, as the docosahexaenoic acid and arachidonic acid in breast milk may affect retinal and neural development, therefore decreasing the risk of myopia. ${ }^{23}$

Here, we sought to study the effects of multiple prenatal/ genetic, perinatal and postnatal factors on the development of myopia-related VIUC in primary and middle school students in the Guangzhou area of China. For this study, the Health Promotion Centre for Primary and Secondary Schools of Guangzhou Municipality released an annual online health survey of primary and secondary school students, and we subsequently received relevant information from this institution. We used descriptive statistics, logistic analysis and multiple logistic regression models to analyse the data and explore the relationships between various environmental factors, parental myopia, prenatal and neonatal factors and myopia. Our results improve our understanding of the aetiology of childhood myopia in East Asia and confirm known potential prenatal factors for long-term diseases.

\section{METHODS}

\section{Data source}

The studies involving human subjects were conducted in accordance with the Declaration of Helsinki guidelines. A cross-sectional survey design was used, and a health survey was conducted by the Health Promotion Centre for Primary and Secondary Schools of Guangzhou Municipality, which is responsible for monitoring the health status of primary and middle schools in Guangzhou. All of the primary and middle school students in Guangzhou were invited by their school to participate in the survey in October 2017. Consent was provided to all of the participants by school teachers, and oral informed consent was obtained from the participants' parents. All of the parents of school students were informed about this study at the parent-teacher conference, using posters and a short messaging service. Only verbal consent was obtained as this study was a health survey.

The health survey covered 11 administrative districts in Guangzhou, including 991 schools. In total, 253301 questionnaires were collected. On the first page of the questionnaire, it was stated that the results of the health questionnaire would be used for health research.
According to the Education Statistics Manual of Guangzhou in 2017, the number of primary and middle school students in 2017 was 1 514122, so the response rate of this survey was $16.73 \%$.

This health survey consisted of a questionnaire and a physical examination. The questionnaire was divided into four parts, including basic conditions, psychological behaviour, exercise and sleep and diet. Only the part of basic conditions was used in this study. Children and parents jointly filled out the questionnaire on the Internet according to their own situation and submitted the questionnaire directly online. This study used the first part of the data, including aspects such as birth weight, sex, neonatal feeding, delivery mode, delivery date, maternal diseases in pregnancy, parents' education, parental myopia, parental smoking and average monthly household income per person.

\section{Visual acuity assessment}

The students' uncorrected visual acuity (UCVA) was examined in all schools by trained optometrists by the same standard logarithmic visual acuity charts (Chinese standard for logarithmic visual acuity charts, GB11533-2011) on a light box with 300 to 500 lux illumination, following regular procedures. ${ }^{24}$ During the test, students sat at a $5 \mathrm{~m}$ distance from the chart with one eye covered and read out the direction of the letter ' $E$ '. Students pointed in the direction the letter ' $E$ ' was facing: up, down, left or right. The test started at the 6/6 line. If students cannot see clearly, they go up one line at a time; otherwise, they go down one line at a time. The identification time of each ' $\mathrm{E}$ ' must not exceed $5 \mathrm{~s}$. This process was repeated with the other eye. It is stipulated that there was no misidentification in $6 / 60$ to $6 / 20$ lines on each line, and less than two errors on each line of $6 / 15$ to $6 / 6$ lines and less than three errors on each line of $6 / 5$ to $6 / 3$. If the top line could not be read at $5 \mathrm{~m}$, the student was tested at $2.5 \mathrm{~m}$ or $1 \mathrm{~m}$, and the measured visual acuity was subtracted by 0.3 or 0.7 , respectively, and then recorded as the student's visual acuity.

\section{Patient and public involvement}

Patients or the public were not involved in the design, or conduct, or reporting, or dissemination plans of our research.

\section{Statistical methods}

Characteristics of participants are presented as mean (SD) for continuous variables and as frequency (proportion) for categorical variables. VIUC was defined according to UCVA (better eye) (UCVA <6/12) with three levels: light VI (visual impairment) (UCVA $\geq 6 / 18$ to $<6 / 12$ ), mild VI (UCVA $\geq 6 / 60$ to $<6 / 18$ ) and severe VI (UCVA $<6 / 60$ ), referring to the previous studies and definitions of impaired vision by the WHO.$^{25}$ The prevalence $(95 \%$ CI) of VIUC was estimated by categorisation of the participants' characteristics. The prevalence between categories was compared using logistic regression. Multiple 
logistic regression analysis was performed to detect the potential risk factors for VIUC. The participants who were singletons with normal birth weights (2.5 to $4 \mathrm{~kg}$ ) and whose mothers had no pregnancy disorders during pregnancy were included in the regression analysis. Two binary outcomes of VIUC were defined by UCVA (better eye) $<6 / 12 \quad(\geq 6 / 12$ as reference) and UCVA (better eye $)<6 / 18 \quad(\geq 6 / 18$ as reference). Observations with missing values for the response or explanatory variables were excluded in the logistic regression analysis. Variables with $\mathrm{p}<0.05$ in the simple regression analysis were included in the multiple regression model. All of the $p$ values were based on two-sided tests, where $\mathrm{p}<0.05$ was considered as statistically significant. Statistical analyses were performed using SAS V.9.4 (SAS Institute Inc, Cary, North Carolina, USA).

\section{RESULTS}

\section{Characteristics of participants}

Characteristics of all of the participants are presented in table 1.The mean age of school grade 1 in China is 6 years old. All of the factors can be grouped into (1) prenatal/ genetic factors, including the father's refractive error, the mother's refractive error, parental myopia and one or both parents' education; (2) perinatal factors, including birth weight, neonatal feeding, delivery mode, delivery date and diseases in pregnancy; and (3) postnatal factors, including grade, age, sex, only child status, parents' smoking, average time spent on homework per day and average time spent on outdoor activities per day.

In brief, the parental refractive error was divided into three levels: namely $-3.00 \mathrm{D},-3.00 \mathrm{D}$ to $-6.00 \mathrm{D}$ and less than $-6.00 \mathrm{D}$. The results showed that the distributions of the father's refractive error were $13.8 \%, 8.28 \%$ and $1.37 \%$, and those of the mother's refractive error were $16.6 \%, 9.63 \%$ and $1.66 \%$ (table 1). Both parents had myopia, and neither of them had myopia in $14.0 \%$ and $58.8 \%$ of the cases, while only the father or the mother had myopia in $11.5 \%$ and $15.8 \%$ of the cases, respectively. One or both parents' education was more than 12 years in $74.4 \%$ of the cases (table 1 ).

There were three ways of neonatal feeding: breast feeding only, formula feeding only and breast feeding and formula feeding together, accounting for $38.8 \%$, $26.7 \%$ and $34.6 \%$, respectively. Vaginal delivery accounted for $63.5 \%$, while the caesarean section delivery rate was $36.5 \%$. The proportion of maternal gestational diseases, including hypertension, diabetes, intrahepatic cholestasis, hypothyroidism, hyperthyroidism, anaemia and viral hepatitis, was $11.3 \%$. The average birth weight was $2.99 \mathrm{~kg} \pm 0.40 \mathrm{~kg}$ (table 1 ).

In addition, students of primary school (grade 1 to 6), junior middle school (grade 7 to 9 ) and high middle school (grade 10 to 12) represented $74.6 \%, 17.8 \%$ and $7.57 \%$ of the total study population, respectively, with $53.8 \%$ being male. Less than 1 hour, 1 to 2 hours, 2 to 3 hours and more than 3 hours spent on homework per

\begin{tabular}{|c|c|c|}
\hline Characteristics & $\mathbf{N}$ & N (\%) \\
\hline Total & 253301 & \\
\hline Grade & 253301 & \\
\hline $1-6$ & & 189008 (74.6) \\
\hline $7-9$ & & $45119(17.8)$ \\
\hline $10-12$ & & $19174(7.57)$ \\
\hline $\mathrm{Age}^{\star}$ & 253301 & \\
\hline $6-10$ & & $156992(62.0)$ \\
\hline $11-15$ & & $82092(32.4)$ \\
\hline$>15$ & & $14217(5.61)$ \\
\hline Sex & 253301 & \\
\hline Male & & $136200(53.8)$ \\
\hline Female & & 117101 (46.2) \\
\hline Birth weight, kg & 249610 & $2.99(0.40) \dagger$ \\
\hline Neonatal feeding & 253292 & \\
\hline Breast feeding & & 98164 (38.8) \\
\hline Breast + formula feeding & & $87532(34.6)$ \\
\hline Formula feeding & & $67596(26.7)$ \\
\hline Delivery & 253292 & \\
\hline Vaginal delivery & & $160873(63.5)$ \\
\hline Caesarean & & $92419(36.5)$ \\
\hline Delivery date & 253291 & \\
\hline On the due date & & $91409(36.1)$ \\
\hline Overdue & & $54161(21.4)$ \\
\hline Before the due date & & $107721(42.5)$ \\
\hline \multicolumn{3}{|l|}{ Diseases in pregnancy } \\
\hline Hypertension & 252013 & $3722(1.48)$ \\
\hline Diabetes & 252068 & $5237(2.08)$ \\
\hline Intrahepatic cholestasis & 251930 & $622(0.25)$ \\
\hline Hypothyroidism & 251878 & $764(0.30)$ \\
\hline Hyperthyroidism & 248301 & $978(0.39)$ \\
\hline Anaemia & 248374 & $16236(6.54)$ \\
\hline Viral hepatitis & 248311 & $2330(0.94)$ \\
\hline Other & 248273 & $1679(0.68)$ \\
\hline Any disease above & 248461 & $27998(11.3)$ \\
\hline Children without siblings & 253286 & \\
\hline No & & $139318(55.0)$ \\
\hline Yes & & $113968(45.0)$ \\
\hline $\begin{array}{l}\text { One or both parents' } \\
\text { education }\end{array}$ & 253288 & \\
\hline$<=12$ years & & 64943 (25.6) \\
\hline$>12$ years & & $188345(74.4)$ \\
\hline Father smoking & 253286 & \\
\hline Never smoked & & $138077(54.5)$ \\
\hline Quit for $>1$ year & & 17998 (7.11) \\
\hline Quit for $<1$ year & & $5362(2.12)$ \\
\hline Current smoking & & 91849 (36.3) \\
\hline Mother smoking & 253286 & \\
\hline Never smoked & & 251159 (99.2) \\
\hline Quit for $>1$ year & & $900(0.36)$ \\
\hline
\end{tabular}




\begin{tabular}{|c|c|c|}
\hline Characteristics & $\mathbf{N}$ & N (\%) \\
\hline Quit for $<1$ year & & $276(0.11)$ \\
\hline Current smoking & & $951(0.38)$ \\
\hline $\begin{array}{l}\text { Father's refractive error, } \\
\text { diopter }\end{array}$ & 238888 & \\
\hline Normal & & 182857 (76.6) \\
\hline$>-3.00 \mathrm{D}$ & & $32982(13.8)$ \\
\hline$<=-3.00 \mathrm{D}$ to $>=-6.00 \mathrm{D}$ & & $19770(8.28)$ \\
\hline$<-6.00 \mathrm{D}$ & & $3279(1.37)$ \\
\hline $\begin{array}{l}\text { Mother's refractive error, } \\
\text { diopter }\end{array}$ & 240291 & \\
\hline Normal & & $173256(72.1)$ \\
\hline$>-3.00 \mathrm{D}$ & & 39915 (16.6) \\
\hline$<=-3.00 \mathrm{D}$ to $>=-6.00 \mathrm{D}$ & & 23135 (9.63) \\
\hline$<-6.00 \mathrm{D}$ & & $3985(1.66)$ \\
\hline Parental myopia & 242006 & \\
\hline Two of them were normal & & $142238(58.8)$ \\
\hline Only father having myopia & & 27794 (11.5) \\
\hline Only mother having myopia & & $38172(15.8)$ \\
\hline Two of them having myopia & & $33802(14.0)$ \\
\hline $\begin{array}{l}\text { Average time for homework } \\
\text { per day, hour }\end{array}$ & 251925 & \\
\hline$<=1$ & & $75123(29.8)$ \\
\hline $1-2$ & & $90674(36.0)$ \\
\hline $2-3$ & & $59901(23.8)$ \\
\hline$>3$ & & $26227(10.4)$ \\
\hline $\begin{array}{l}\text { Average time for outdoor } \\
\text { activities per day, hour }\end{array}$ & 253280 & \\
\hline$<1$ & & $114471(45.2)$ \\
\hline $1-2$ & & $101658(40.1)$ \\
\hline $2-4$ & & $27332(10.8)$ \\
\hline$>4$ & & 9819 (3.88) \\
\hline
\end{tabular}

*The mean age of school grade 1 is 6 years old. †Data is represented as mean (SD).

day were reported in $29.8 \%, 36.0 \%, 23.8 \%$ and $10.4 \%$ of the cases, respectively; less than 1 hour, 1 to 2 hours, 2 to 4 hours and more than 4 hours spent on outdoor activities per day were reported in $45.2 \%, 40.1 \%, 10.8 \%$ and $3.88 \%$ of the cases, respectively. Children without siblings made up $45.0 \%$. Paternal and maternal smoking rates were $45.5 \%$ and $0.85 \%$, respectively (table 1 ). The smoking rates and the number of siblings in this study were comparable to the norm of China according to recent reports. ${ }^{26} 27$

\section{Prevalence of VIUC by characteristics}

Of the 253301 children included in the present study, $15.7 \%$ children experienced VIUC (table 2). The larger the refraction error of either the father or the mother, the higher the prevalence of all levels of VIUC in children. Additionally, more time spent on homework per day and less time spent on outdoor activities per day was associated with a higher risk of VIUC (all $\mathrm{p}<0.001$ ).

The prevalence of all three levels of VIUC was similar in the subgroups with different modes of neonatal feeding, but breast feeding and formula feeding together showed statistically significant differences compared with breast feeding only (all $\mathrm{p}<0.01$, table 2 ). Caesarean section was associated with a higher prevalence of severe VIUC $(p<0.001)$ but with a lower prevalence of light VIUC $(p<0.001)$, mild VIUC $(p<0.05)$ and overall VIUC $(p<0.05)$. Unexpectedly, the prevalence of UCVA $<6 / 12$ in participants born before their due date was lower than in participants born on their due date $(16.7 \%, \mathrm{p}<0.001)$ or who were overdue $(16.2 \%, \mathrm{p}<0.001)$. Maternal pregnancy diseases were significantly associated with an increased risk of VIUC (table 2).

With increasing grade and age, the prevalence of UCVA $<6 / 12$ also increased (all $\mathrm{p}<0.001$ ); the prevalence among students in grades 10 to 12 and students older than 15 years was $51.4 \%$ and $52.4 \%$, respectively (table 2). The increase in the prevalence of severe VIUC, which was $9.92 \%$ and $10.6 \%$, respectively, was most significant (all $\mathrm{p}<0.001)$. The prevalence of UCVA $<6 / 12$ was different $(\mathrm{p}<0.001)$ in female $(17.8 \%)$ and male $(13.9 \%)$ participants. The prevalence of all levels of VIUC was higher among children without siblings than among children with siblings. The prevalence of UCVA (better eye) $<6 / 12$ or worse than $6 / 18$ was higher among students with one or both parents' education $>12$ years than among students with both parents' education $\leq 12$ years (table 2 ). Students with a father currently smoking had a lower risk of VIUC (all $\mathrm{p}<0.05)$.

\section{Multiple logistic regression model for detecting the potential risk factors for VIUC}

The results of two multiple logistic regression models for detecting the potential risk factors for VIUC are presented in table 3 , with $6 / 12(\geq 6 / 12$ as reference) and $6 / 18$ ( $\geq 6 / 18$ as reference) as cut-off points. Because low birth weight and maternal diseases are known factors affecting children's eye development, here, we only studied the 155556 participants who were singletons with normal birth weights (2.5 to $4 \mathrm{~kg}$ ) and whose mothers had no disease during pregnancy.

The results indicated that the students whose parents had a higher level of education had a higher risk of UCVA $<6 / 18$ (OR (95\% CI), 1.10 (1.04 and 1.16); p<0.001) (table 3). Parental myopia increased the risk of UCVA $<6 / 12$ or $<6 / 18$ (all $\mathrm{p}<0.001$ ) when only the father had myopia (OR (95\% CI), 1.97 (1.87 to 2.07) and 1.98 (1.87 to 2.11$)$ ), when only the mother had myopia (OR (95\% CI), 1.80 (1.72 to 1.89 ) and 1.83 (1.73 to 1.94)) and when both parents had myopia (OR (95\% CI), 2.96 (2.82 to 3.10 ) and 3.09 (2.92 to 3.27)).

In addition, birth weight was only positively associated with UCVA <6/18 (OR (95\% CI), 1.11 (1.05 to 1.17); $\mathrm{p}<0.001)$. Compared with breast feeding only, formula feeding only contributed to a higher risk of UCVA $<6 / 12$ 
Table 2 Prevalence of VIUC by characteristics

\begin{tabular}{|c|c|c|c|c|}
\hline & $\begin{array}{l}\text { Total } \\
\text { UCVA }<6 / 12 \\
\end{array}$ & $\begin{array}{l}\text { Light VIUC } \\
\text { UCVA }>=6 / 18 \text { to }<6 / 12\end{array}$ & $\begin{array}{l}\text { Mild VIUC } \\
\text { UCVA }>=6 / 60 \text { to }<6 / 18\end{array}$ & $\begin{array}{l}\text { Severe VIUC } \\
\text { UCVA }<6 / 60\end{array}$ \\
\hline Variable & $\%(95 \% \mathrm{Cl}) \dagger$ & $\%(95 \% \mathrm{Cl}) \dagger$ & $\%(95 \% \mathrm{Cl}) \dagger$ & $\%(95 \% \mathrm{Cl}) \dagger$ \\
\hline All & 15.7 (15.6 to 15.9$)$ & 6.11 (6.00 to 6.22$)$ & 8.12 (8.00 to 8.24$)$ & 1.49 (1.44 to 1.54$)$ \\
\hline \multicolumn{5}{|l|}{ Grade } \\
\hline $1-6$ & 6.71 (6.58 to 6.85 ) & 3.70 (3.60 to 3.80 ) & 2.85 (2.76 to 2.94$)$ & $0.16(0.14$ to 0.18$)$ \\
\hline $7-9$ & $30.0(29.6 \text { to } 30.5)^{\star \star \star}$ & $11.6(11.3 \text { to } 11.9)^{\star \star \star}$ & $16.2(15.8 \text { to } 16.5)^{\star \star \star}$ & $2.25(2.10 \text { to } 2.39)^{\star \star \star}$ \\
\hline $10-12$ & $51.4(50.6 \text { to } 52.1)^{\star \star \star}$ & $11.7(11.2 \text { to } 12.2)^{* \star \star}$ & $29.7(29.1 \text { to } 30.4)^{\star \star \star}$ & $9.92(9.47 \text { to } 10.4)^{\star \star *}$ \\
\hline \multicolumn{5}{|l|}{ Age, years } \\
\hline $6-10$ & 4.56 (4.43 to 4.69$)$ & 2.66 (2.56 to 2.76 ) & 1.80 (1.72 to 1.88$)$ & 0.10 (0.08 to 0.12$)$ \\
\hline $11-15$ & $25.1(24.8 \text { to } 25.4)^{\star \star \star}$ & $10.1(9.85 \text { to } 10.3)^{\star \star \star}$ & $13.1(12.9 \text { to } 13.4)^{\star \star \star}$ & $1.88(1.79 \text { to } 1.98)^{\star \star \star}$ \\
\hline$>15$ & $52.4(51.5 \text { to } 53.3)^{\star \star \star}$ & $11.3(10.7 \text { to } 11.8)^{\star \star \star}$ & $30.6(29.8 \text { to } 31.4)^{\star \star \star}$ & $10.6(10.0 \text { to } 11.1)^{\star \star \star}$ \\
\hline \multicolumn{5}{|l|}{ Sex } \\
\hline Female & 17.8 (17.5 to 18.0$)$ & 6.75 (6.58 to 6.91$)$ & 9.33 (9.14 to 9.52$)$ & 1.70 (1.62 to 1.79$)$ \\
\hline Male & $13.9(13.7 \text { to } 14.1)^{\star \star \star}$ & $5.55(5.41 \text { to } 5.69)^{\star \star \star}$ & $7.07(6.91 \text { to } 7.22)^{\star \star \star}$ & $1.30(1.24 \text { to } 1.37)^{\star \star \star}$ \\
\hline \multicolumn{5}{|l|}{ Neonatal feeding } \\
\hline Breast feeding & 16.1 (15.9 to 16.4$)$ & $6.42(6.24$ to 6.60$)$ & 8.22 (8.02 to 8.42$)$ & $1.49(1.40$ to 1.57$)$ \\
\hline $\begin{array}{l}\text { Breast }+ \text { formula } \\
\text { feeding }\end{array}$ & $15.2(14.9 \text { to } 15.5)^{\star \star \star}$ & $5.71(5.53 \text { to } 5.89)^{\star \star \star}$ & $7.80(7.60 \text { to } 8.01)^{\star \star}$ & $1.67(1.57 \text { to } 1.76)^{* *}$ \\
\hline Formula feeding & 15.8 (15.5 to 16.1$)$ & 6.16 (5.96 to 6.37$)$ & 8.38 (8.14 to 8.62$)$ & $1.27(1.17 \text { to } 1.36)^{\star *}$ \\
\hline \multicolumn{5}{|l|}{ Delivery } \\
\hline Vaginal delivery & 15.9 (15.6 to 16.1$)$ & 6.31 (6.17 to 6.44$)$ & 8.22 (8.06 to 8.37 ) & $1.32(1.26$ to 1.39$)$ \\
\hline Caesarean & $15.5(15.2 \text { to } 15.8)^{\star}$ & $5.77(5.60 \text { to } 5.94)^{\star \star \star}$ & $7.95(7.75 \text { to } 8.15)^{\star}$ & $1.77(1.67 \text { to } 1.87)^{\star * \star}$ \\
\hline \multicolumn{5}{|l|}{ Delivery date } \\
\hline Due date & 16.7 (16.4 to 17.0$)$ & 6.56 (6.37 to 6.74$)$ & 8.82 (8.60 to 9.03 ) & 1.31 (1.23 to 1.40$)$ \\
\hline Overdue & $16.2(15.9 \text { to } 16.6)^{\star}$ & $6.20(5.97 \text { to } 6.43)^{*}$ & $8.29(8.02 \text { to } 8.55)^{\star \star}$ & $1.73(1.61 \text { to } 1.86)^{\star \star \star}$ \\
\hline Before due date & $14.7(14.4 \text { to } 14.9)^{\star \star \star}$ & $5.68(5.52 \text { to } 5.84)^{\star \star \star}$ & $7.45(7.27 \text { to } 7.63)^{\star \star \star}$ & $1.52(1.43 \text { to } 1.60)^{\star * \star}$ \\
\hline \multicolumn{5}{|c|}{ Diseases in pregnancy } \\
\hline \multicolumn{5}{|c|}{ Hypertension } \\
\hline No & 15.7 (15.5 to 15.9$)$ & 6.10 (5.99 to 6.21$)$ & 8.12 (8.00 to 8.25$)$ & $1.48(1.43$ to 1.54$)$ \\
\hline Yes & $17.5(16.1 \text { to } 18.9)^{\star \star}$ & $7.22(6.26 \text { to } 8.18)^{*}$ & 8.18 (7.17 to 9.19$)$ & $2.13(1.60 \text { to } 2.67)^{\star \star}$ \\
\hline \multicolumn{5}{|l|}{ Diabetes } \\
\hline No & 15.8 (15.6 to 16.0$)$ & $6.13(6.02$ to 6.24$)$ & 8.17 (8.04 to 8.29$)$ & 1.49 (1.43 to 1.54$)$ \\
\hline Yes & $12.7(11.6 \text { to } 13.8)^{\star \star \star}$ & $5.31(4.57 \text { to } 6.05)^{\star}$ & $5.82(5.05 \text { to } 6.59)^{\star \star \star}$ & 1.60 (1.19 to 2.01$)$ \\
\hline \multicolumn{5}{|l|}{$\begin{array}{l}\text { Intrahepatic } \\
\text { cholestasis }\end{array}$} \\
\hline No & 15.7 (15.6 to 15.9$)$ & $6.12(6.01$ to 6.23$)$ & 8.13 (8.01 to 8.25$)$ & 1.49 (1.44 to 1.55$)$ \\
\hline Yes & $11.9(8.84 \text { to } 14.9)^{*}$ & 4.79 (2.79 to 6.80$)$ & 5.71 (3.54 to 7.88 ) & 1.37 (0.28 to 2.46$)$ \\
\hline \multicolumn{5}{|l|}{ Hypothyroidism } \\
\hline No & 15.7 (15.6 to 15.9$)$ & 6.11 (6.01 to 6.22$)$ & $8.13(8.00$ to 8.25$)$ & 1.49 (1.44 to 1.55$)$ \\
\hline Yes & 14.0 (11.0 to 17.0$)$ & 5.83 (3.80 to 7.85$)$ & 6.99 (4.79 to 9.19$)$ & 1.17 (0.24 to 2.09$)$ \\
\hline \multicolumn{5}{|l|}{ Hyperthyroidism } \\
\hline No & 15.8 (15.6 to 15.9$)$ & 6.12 (6.01 to 6.23$)$ & 8.15 (8.03 to 8.28$)$ & 1.50 (1.45 to 1.56$)$ \\
\hline Yes & 16.0 (13.3 to 18.7$)$ & 6.93 (5.06 to 8.80$)$ & 7.92 (5.93 to 9.91$)$ & 1.13 (0.35 to 1.91$)$ \\
\hline \multicolumn{5}{|l|}{ Anaemia } \\
\hline No & $16.0(15.8$ to 16.1$)$ & 6.15 (6.04 to 6.27$)$ & 8.28 (8.16 to 8.41$)$ & 1.53 (1.47 to 1.59$)$ \\
\hline Yes & $12.9(12.3 \text { to } 13.5)^{\star \star \star}$ & $5.64(5.22 \text { to } 6.06)^{\star}$ & $6.16(5.73 \text { to } 6.60)^{\star \star \star}$ & $1.08(0.89 \text { to } 1.26)^{\star \star \star}$ \\
\hline
\end{tabular}


Table 2 Continued

\begin{tabular}{|c|c|c|c|c|}
\hline & $\begin{array}{l}\text { Total } \\
\text { UCVA }<6 / 12\end{array}$ & $\begin{array}{l}\text { Light VIUC } \\
\text { UCVA }>=6 / 18 \text { to }<6 / 12\end{array}$ & $\begin{array}{l}\text { Mild VIUC } \\
\text { UCVA }>=6 / 60 \text { to }<6 / 18\end{array}$ & $\begin{array}{l}\text { Severe VIUC } \\
\text { UCVA }<6 / 60\end{array}$ \\
\hline Variable & $\%(95 \% \mathrm{Cl}) \dagger$ & $\%(95 \% \mathrm{Cl}) \dagger$ & $\%(95 \% \mathrm{Cl}) \dagger$ & $\%(95 \% \mathrm{Cl}) \dagger$ \\
\hline \multicolumn{5}{|l|}{ Viral hepatitis } \\
\hline No & 15.8 (15.6 to 16.0$)$ & 6.12 (6.01 to 6.23$)$ & 8.17 (8.05 to 8.29$)$ & 1.51 (1.45 to 1.56$)$ \\
\hline Yes & $13.2(11.6 \text { to } 14.8)^{\star \star}$ & 5.97 (4.85 to 7.09$)$ & $6.32(5.17 \text { to } 7.47)^{\star \star}$ & $0.93(0.48$ to 1.38$)$ \\
\hline \multicolumn{5}{|l|}{ Other } \\
\hline No & 15.8 (15.6 to 15.9$)$ & 6.12 (6.01 to 6.23$)$ & 8.15 (8.03 to 8.28$)$ & 1.51 (1.45 to 1.56$)$ \\
\hline Yes & 15.2 (13.2 to 17.2$)$ & 6.47 (5.07 to 7.86$)$ & 7.89 (6.36 to 9.42$)$ & 0.84 (0.32 to 1.36$)$ \\
\hline \multicolumn{5}{|l|}{ Any disease above } \\
\hline No & 16.0 (15.9 to 16.2 ) & 6.15 (6.04 to 6.27$)$ & 8.36 (8.22 to 8.49$)$ & $1.52(1.46$ to 1.58$)$ \\
\hline Yes & $13.6(13.1 \text { to } 14.1)^{\star \star \star}$ & 5.82 (5.50 to 6.15$)$ & $6.47(6.13 \text { to } 6.81)^{\star \star \star}$ & $1.31(1.15 \text { to } 1.46)^{*}$ \\
\hline \multicolumn{5}{|c|}{ Children without siblings } \\
\hline No & 13.4 (13.2 to 13.6$)$ & 5.75 (5.61 to 5.89$)$ & 6.84 (6.69 to 7.00$)$ & 0.76 (0.71 to 0.081$)$ \\
\hline Yes & $18.5(18.3 \text { to } 18.8)^{\star \star \star}$ & $6.53(6.37 \text { to } 6.70)^{\star \star \star}$ & $9.65(9.45 \text { to } 9.85)^{\star \star \star}$ & $2.36(2.26 \text { to } 2.46)^{\star \star \star}$ \\
\hline \multicolumn{5}{|c|}{ One or both parents' education } \\
\hline$<=12$ years & 14.0 (13.7 to 14.4$)$ & 6.12 (5.91 to 6.33 ) & 7.39 (7.15 to 7.62$)$ & 0.53 (0.47 to 0.60$)$ \\
\hline$>12$ years & $16.3(16.1 \text { to } 16.5)^{\star \star \star}$ & 6.10 (5.98 to 6.23$)$ & $8.37(8.22 \text { to } 8.51)^{\star \star \star}$ & $1.81(1.74 \text { to } 1.88)^{\star \star \star}$ \\
\hline \multicolumn{5}{|l|}{ Father smoking } \\
\hline Never smoked & 16.1 (15.9 to 16.3 ) & 6.15 (6.01 to 6.30$)$ & 8.38 (8.21 to 8.55$)$ & 1.56 (1.48 to 1.64$)$ \\
\hline Quit for $>1$ year & $17.8(17.2 \text { to } 18.5)^{\star \star \star}$ & $6.83(6.41 \text { to } 7.25)^{\star \star}$ & $9.23(8.74 \text { to } 9.71)^{\star \star \star}$ & 1.76 (1.54 to 1.97$)$ \\
\hline Quit for $<1$ year & 15.4 (14.3 to 16.5$)$ & 6.41 (5.65 to 7.18$)$ & 7.81 (6.97 to 8.64$)$ & 1.19 (0.85 to 1.53$)$ \\
\hline Current smoking & $14.8(14.5 \text { to } 15.0)^{\star \star \star}$ & $5.88(5.70 \text { to } 6.05)^{\star}$ & $7.52(7.33 \text { to } 7.72)^{\star \star \star}$ & $1.35(1.26 \text { to } 1.43)^{\star * \star}$ \\
\hline \multicolumn{5}{|c|}{ Father's refractive error, diopter } \\
\hline Normal & 13.9 (13.7 to 14.1$)$ & 5.67 (5.55 to 5.79 ) & 7.17 (7.03 to 7.30$)$ & 1.04 (0.99 to 1.09$)$ \\
\hline$>-3.00 \mathrm{D}$ & $20.4(19.9 \text { to } 20.9)^{\star \star \star}$ & $7.31(6.99 \text { to } 7.64)^{\star \star \star}$ & $10.5(10.1 \text { to } 10.9)^{\star \star \star}$ & $2.66(2.45 \text { to } 2.86)^{\star * *}$ \\
\hline $\begin{array}{l}<=-3.00 \mathrm{D} \text { to } \\
>=-6.00 \mathrm{D}\end{array}$ & $23.4(22.8 \text { to } 24.1)^{\star \star \star}$ & $7.35(6.92 \text { to } 7.77)^{\star \star \star}$ & $12.5(12.0 \text { to } 13.0)^{\star \star \star}$ & $3.60(3.30 \text { to } 3.90)^{* * *}$ \\
\hline$<-6.00 \mathrm{D}$ & $27.3(25.5 \text { to } 29.0)^{\star \star \star}$ & $8.01(6.93 \text { to } 9.08)^{\star \star \star}$ & $14.1(12.7 \text { to } 15.4)^{\star \star \star}$ & $5.19(4.31 \text { to } 6.14)^{\star * *}$ \\
\hline \multicolumn{5}{|c|}{ Mother's refractive error, in either eye, diopter } \\
\hline Normal & 14.1 (13.9 to 14.3$)$ & 5.70 (5.57 to 5.82$)$ & $7.31(7.16$ to 7.45$)$ & 1.07 (1.02 to 1.13$)$ \\
\hline$>-3.00 \mathrm{D}$ & $18.9(18.5 \text { to } 19.3)^{\star \star \star}$ & $6.82(6.53 \text { to } 7.11)^{\star \star \star}$ & $9.79(9.45 \text { to } 10.1)^{\star \star \star}$ & $2.29(2.12 \text { to } 2.46)^{\star \star *}$ \\
\hline $\begin{array}{l}<=-3.00 \mathrm{D} \text { to } \\
>=-6.00 \mathrm{D}\end{array}$ & $20.9(20.3 \text { to } 21.5)^{\star \star \star}$ & $7.09(6.70 \text { to } 7.47)^{\star \star \star}$ & $10.6(10.2 \text { to } 11.1)^{\star \star \star}$ & $3.14(2.88 \text { to } 3.40)^{\star * \star}$ \\
\hline$<-6.00 \mathrm{D}$ & $25.8(24.2 \text { to } 27.4)^{\star \star \star}$ & $8.06(7.07 \text { to } 9.05)^{\star \star \star}$ & $13.2(12.0 \text { to } 14.5)^{\star \star \star}$ & $4.49(3.74 \text { to } 5.25)^{\star * *}$ \\
\hline \multicolumn{5}{|l|}{ Parental myopia } \\
\hline $\begin{array}{l}\text { Two of them were } \\
\text { normal }\end{array}$ & 13.1 (12.9 to 13.3$)$ & 5.44 (5.30 to 5.57$)$ & 6.77 (6.62 to 6.92$)$ & $0.86(0.80$ to 0.91$)$ \\
\hline $\begin{array}{l}\text { Only father having } \\
\text { myopia }\end{array}$ & $19.3(18.8 \text { to } 19.8)^{\star \star \star}$ & $7.02(6.67 \text { to } 7.36)^{\star \star \star}$ & $10.1(9.69 \text { to } 10.5)^{\star \star \star}$ & $2.19(1.99 \text { to } 2.39)^{\star * *}$ \\
\hline $\begin{array}{l}\text { Only mother } \\
\text { having myopia }\end{array}$ & $16.8(16.4 \text { to } 17.2)^{\star \star \star}$ & $6.46(6.18 \text { to } 6.75)^{\star \star \star}$ & $8.58(8.25 \text { to } 8.90)^{\star \star *}$ & $1.75(1.60 \text { to } 1.90)^{* \star *}$ \\
\hline $\begin{array}{l}\text { Two of them } \\
\text { having myopia }\end{array}$ & $23.1(22.6 \text { to } 23.7)^{\star \star \star}$ & $7.64(7.31 \text { to } 7.97)^{\star \star \star}$ & $11.9(11.5 \text { to } 12.3)^{\star \star \star}$ & $3.55(3.32 \text { to } 3.78)^{\star \star \star}$ \\
\hline \multicolumn{5}{|c|}{ Average time for homework per day, hour } \\
\hline$<=1$ & 15.1 (14.8 to 15.4$)$ & 6.13 (5.92 to 6.34$)$ & 7.93 (7.70 to 8.17$)$ & 1.00 (0.91 to 1.08$)$ \\
\hline $1-2$ & $12.4(12.1 \text { to } 12.6)^{\star \star \star}$ & $5.42(5.25 \text { to } 5.59)^{\star \star \star}$ & $6.16(5.97 \text { to } 6.34)^{\star \star \star}$ & $0.81(0.75 \text { to } 0.88)^{\star \star \star}$ \\
\hline
\end{tabular}


Table 2 Continued

\begin{tabular}{|c|c|c|c|c|}
\hline & $\begin{array}{l}\text { Total } \\
\text { UCVA }<6 / 12\end{array}$ & $\begin{array}{l}\text { Light VIUC } \\
\text { UCVA }>=6 / 18 \text { to }<6 / 12\end{array}$ & $\begin{array}{l}\text { Mild VIUC } \\
\text { UCVA }>=6 / 60 \text { to }<6 / 18\end{array}$ & $\begin{array}{l}\text { Severe VIUC } \\
\text { UCVA }<6 / 60\end{array}$ \\
\hline Variable & $\%(95 \% \mathrm{Cl}) \dagger$ & $\%(95 \% \mathrm{Cl}) \dagger$ & $\%(95 \% \mathrm{Cl}) \dagger$ & $\%(95 \% \mathrm{Cl}) \dagger$ \\
\hline$>3$ & $24.1(23.5 \text { to } 24.6)^{\star \star \star}$ & $7.49(7.15 \text { to } 7.83)^{\star \star \star}$ & $12.6(12.2 \text { to } 13.1)^{\star \star \star}$ & $3.96(3.70 \text { to } 4.21)^{\star \star \star}$ \\
\hline \multicolumn{5}{|c|}{ Average time for outdoor activities per day, hour } \\
\hline $1-2$ & $15.0(14.8 \text { to } 15.3)^{\star \star \star}$ & 5.99 (5.82 to 6.16$)$ & $7.66(7.47 \text { to } 7.85)^{\star \star \star}$ & $1.38(1.30 \text { to } 1.47)^{\star \star \star}$ \\
\hline $2-4$ & $15.0(14.5 \text { to } 15.4)^{\star \star \star}$ & 6.18 (5.85 to 6.51$)$ & $7.74(7.38 \text { to } 8.10)^{\star \star \star}$ & $1.04(0.90 \text { to } 1.17)^{\star \star \star}$ \\
\hline$>4$ & $15.2(14.4 \text { to } 16.1)^{\star \star}$ & 6.29 (5.74 to 6.83 ) & $7.94(7.33 \text { to } 8.54)^{*}$ & $1.02(0.79 \text { to } 1.24)^{\star \star \star}$ \\
\hline
\end{tabular}

${ }^{*} \mathrm{p}<0.05,{ }^{* *} \mathrm{p}<0.01,{ }^{* * *} \mathrm{p}<0.001$ indicating the significance of the difference from the reference group.

†Logistic regression was used for comparisons between categories. Prevalence $(95 \% \mathrm{Cl})$ was presented.

$\ddagger V I U C$ was defined by uncorrected visual acuity in better-seeing eye (UCVA). Light VIUC: UCVA $>=6 / 18$ to $<6 / 12$, mild VIUC: UCVA $>=6 / 60$ to $<6 / 18$ and severe VIUC: UCVA $<6 / 60$.

UCVA, uncorrected visual acuity; VIUC, visual impairment without correction.

(OR (95\% CI), 1.14 (1.09 to 1.20$) ; \mathrm{p}<0.001)$, while breast feeding and formula feeding together was associated with a lower risk (OR (95\% CI), 0.96 (0.93 to 1.00$)$; $\mathrm{p}=0.039)$. Delivery mode was not associated with both outcomes of VIUC. Students who were delivered overdue or before due date had a lower risk of UCVA <6/12 (OR (95\% CI), 0.93 ( 0.89 to 0.97 ); $\mathrm{p}=0.002$ and 0.91 (0.87 to 0.94$) ; \mathrm{p}<0.001$, respectively) and UCVA <6/18 (OR (95\% CI), 0.93 (0.88 to 0.98$) ; \mathrm{p}=0.005$ and 0.93 ( 0.89 to 0.98$) ; \mathrm{p}=0.003$, respectively) than those delivered on their due date.

Age (OR (95\% CI), 1.52 (1.51 to 1.53$) ; \mathrm{p}<0.001)$ and not having siblings (OR (95\% CI), 1.09 (1.06 to 1.13); $\mathrm{p}<0.001)$ were positively associated with the risk of UCVA $<6 / 12$. Similarly, age (OR (95\% CI), 1.56 (1.55 to 1.57 ); $\mathrm{p}<0.001)$ and not having siblings (OR $(95 \% \mathrm{CI}), 1.18$ (1.13 to 1.23$) ; \mathrm{p}<0.001)$ were positively associated with the risk of UCVA $<6 / 18$. Male students had a lower risk of either UCVA $<6 / 12$ (OR (95\% CI), 0.77 (0.75 to 0.80); $\mathrm{p}<0.001$ ) or UCVA $<6 / 18$ (OR (95\% CI), 0.78 ( 0.75 to $0.81) ; \mathrm{p}<0.001]$. An average time spent on homework per day of 2 to 3 hours (OR (95\% CI), 1.07 (1.01 to 1.13)) or more than 3 hours (OR (95\% CI), 1.10 (1.03 to 1.17)) was significantly associated with a higher risk of mild VI compared with the group spending less than 1 hour.

In agreement with previous findings, among participants who spent $\geq 1$ hour on outdoor activities, the prevalence of VIUC was lower, that is, for 1 to 2 hours (OR $(95 \%$ CI), 0.95 (0.92 to 0.99 ); $\mathrm{p}=0.006$ and 0.92 (0.88 to 0.96 ); $\mathrm{p}<0.001$ ), for 2 to 4 hours (OR (95\% CI), 0.94 (0.89 to $0.99) ; \mathrm{p}=0.017$ and 0.90 (0.84 to 0.96$) ; \mathrm{p}=0.002)$, and for $>4$ hours $(\mathrm{OR}(95 \% \mathrm{CI}), 0.88$ (0.81 to 0.96$)$; $\mathrm{p}=0.003$ and 0.80 (0.72 to 0.88$) ; \mathrm{p}<0.001)$, compared with participants who spent $<1$ hour on outdoor activities. The current smoking status of the father was associated with a lower risk of UCVA $<6 / 18$ compared with participants with a father who never smoked (OR (95\% CI), 0.94 (0.90 to $0.99) ; \mathrm{p}=0.010)$, and also a marginally significant association between current smoking status of the father and the prevalence of UCVA $<6 / 12$ was observed (OR $(95 \% \mathrm{CI})$, 0.97 (0.93 to 1.00$) ; \mathrm{p}=0.049$ ).

\section{DISCUSSION}

Myopia, the dominant cause of VIUC in teenagers, has increased in prevalence in East Asia in the past few decades and has therefore become a major health issue. ${ }^{28}$ It is commonly believed that the high prevalence of myopia in East Asia is associated with increased educational pressure, combined with lifestyle changes, which have reduced the time children spend outside. ${ }^{2}$ Recent studies have suggested that the development of childhood diseases may also be affected by factors in prenatal and neonatal life, in that factors like delivery mode, feeding manner and pregnancy diseases can alter the risks for childhood diseases such as asthma. ${ }^{29} 30$ However, the prenatal and neonatal factors for VIUC, especially childhood myopia, remain largely unclear. Therefore, a retrospective survey involving primary and middle school students in Guangzhou was launched to evaluate the association between most important prenatal, perinatal and postnatal factors and the prevalence of VIUC in 6-year-old to 17-year-old school students.

The present cross-sectional study, which included 253301 completed questionnaires and medical records, revealed that among children in grades 1 to 6 , grades 7 to 9 and grades 10 to 12 in Guangzhou, the total prevalence of VIUC was $6.71 \%, 30.0 \%$ and $51.4 \%$ and that of severe VIUC was $0.16 \%, 2.25 \%$ and $9.92 \%$, respectively (table 2). The prevalence of VIUC presented here is high compared with other countries and areas but was close to the reported prevalence in Chinese urban areas. ${ }^{31}$ However, as the clustered nature of the data has not been accounted for in the analysis, the width of the CIs may be underestimated. 
Table 3 Multiple logistic regression model for detecting the potential risk factors for VIUC*

\begin{tabular}{|c|c|c|c|c|}
\hline \multirow[b]{2}{*}{ Variable } & \multicolumn{2}{|c|}{ UCVA† $<6 / 12(n=148672) \ddagger$} & \multicolumn{2}{|c|}{ UCVA $<6 / 18(n=148672) \ddagger$} \\
\hline & OR (95\% Cl) & $P$ value & OR $(95 \% \mathrm{Cl})$ & $P$ value \\
\hline Age, year & $1.52(1.51$ to 1.53$)$ & $<0.001$ & 1.56 (1.55 to 1.57$)$ & $<0.001$ \\
\hline Male & 0.77 (0.75 to 0.80$)$ & $<0.001$ & $0.78(0.75$ to 0.81$)$ & $<0.001$ \\
\hline Birth weight, $\mathrm{kg}$ & $1.00(0.96$ to 1.04$)$ & 0.974 & 1.11 (1.05 to 1.17$)$ & $<0.001$ \\
\hline \multicolumn{5}{|l|}{ Neonatal feeding } \\
\hline Breast feeding & Reference & & Reference & \\
\hline Breast + formula feeding & $0.96(0.93$ to 1.00$)$ & 0.039 & / & / \\
\hline Formula feeding & $1.14(1.09$ to 1.20$)$ & $<0.001$ & l & / \\
\hline \multicolumn{5}{|l|}{ Delivery date } \\
\hline Due date & Reference & & Reference & \\
\hline Overdue & $0.93(0.89$ to 0.97$)$ & 0.002 & 0.93 (0.88 to 0.98$)$ & 0.005 \\
\hline Before due date & 0.91 (0.87 to 0.94$)$ & $<0.001$ & 0.93 (0.89 to 0.98$)$ & 0.003 \\
\hline Child without siblings & 1.09 (1.06 to 1.13$)$ & $<0.001$ & 1.18 (1.13 to 1.23$)$ & $<0.001$ \\
\hline One or both parents' education $>12$ years & 1.03 (0.99 to 1.07$)$ & 0.185 & $1.10(1.04$ to 1.16$)$ & $<0.001$ \\
\hline \multicolumn{5}{|c|}{ Father smoking } \\
\hline Never smoked & Reference & & Reference & \\
\hline Quit for $>1$ year & $1.00(0.94$ to 1.07$)$ & 0.893 & 0.94 (0.88 to 1.02$)$ & 0.117 \\
\hline Quit for $<1$ year & 0.97 (0.87 to 1.09$)$ & 0.644 & $0.93(0.81$ to 1.07$)$ & 0.302 \\
\hline Current smoking & 0.97 (0.93 to 1.00$)$ & 0.049 & 0.94 (0.90 to 0.99$)$ & 0.010 \\
\hline \multicolumn{5}{|l|}{ Parental myopia, $\mathrm{n}(\%)$} \\
\hline Two of them were normal & Reference & & Reference & \\
\hline Only father having myopia & 1.97 (1.87 to 2.07$)$ & $<0.001$ & 1.98 (1.87 to 2.11$)$ & $<0.001$ \\
\hline Only mother having myopia & 1.80 (1.72 to 1.89$)$ & $<0.001$ & $1.83(1.73$ to 1.94$)$ & $<0.001$ \\
\hline Two of them having myopia & 2.96 (2.82 to 3.10$)$ & $<0.001$ & 3.09 (2.92 to 3.27$)$ & $<0.001$ \\
\hline \multicolumn{5}{|l|}{ Average time for homework per day, hour } \\
\hline$<=1$ & Reference & & Reference & \\
\hline $1-2$ & 1.00 (0.95 to 1.05$)$ & 0.891 & 0.97 (0.91 to 1.03$)$ & 0.287 \\
\hline $2-3$ & 1.05 (1.00 to 1.10$)$ & 0.059 & 1.07 (1.01 to 1.13$)$ & 0.026 \\
\hline$>3$ & 1.05 (0.99 to 1.11$)$ & 0.092 & $1.10(1.03$ to 1.17$)$ & 0.004 \\
\hline \multicolumn{5}{|c|}{ Average time for outdoor activities per day, hour } \\
\hline$<1$ & Reference & & Reference & \\
\hline $1-2$ & 0.95 (0.92 to 0.99$)$ & 0.006 & 0.92 (0.88 to 0.96$)$ & $<0.001$ \\
\hline $2-4$ & 0.94 (0.89 to 0.99$)$ & 0.017 & $0.90(0.84$ to 0.96$)$ & 0.002 \\
\hline$>4$ & 0.88 (0.81 to 0.96$)$ & 0.003 & 0.80 (0.72 to 0.88$)$ & $<0.001$ \\
\hline
\end{tabular}

*Variables with $p<0.05$ in simple regression analysis were included in the multiple regression model. The results of simple regression analysis were not listed in the table.

†VIUC was defined by uncorrected visual acuity in better-seeing eye (UCVA). Analysis of UCVA $<6 / 12$ ( $>=6 / 12$ as reference) and UCVA $<6 / 18$ (>=6/18 as reference) among participants who were singletons with normal birth weight $(2.5$ to $4 \mathrm{~kg})$ and whose mother had no pregnancy disorder during pregnancy.

$\ddagger$ There were $6882(4.42 \%)$ to $6884(4.43 \%)$ observations excluded due to missing values for the response or explanatory variables. UCVA, uncorrected visual acuity; VIUC, visual impairment without correction.

It is believed that VIUC is aetiologically heterogeneous. A small part of VIUC cases is caused by prenatal and genetic factors and appears without exposure to additional risk factors. ${ }^{5}$ Parental myopia is a high-risk factor for childhood VIUC, but although several genes have been shown to be associated with high myopia, no major genes affecting childhood myopia have been reported until now. ${ }^{2}$ A cohort study of 298 probands with early-onset high myopia using whole-exome sequencing showed that mutations in genes known to be responsible for retinal diseases were found in approximately onefourth of the probands with early-onset high myopia. ${ }^{11}$ In 
another study of myopia prevalence, grade 7 students in a Chinese rural area showed a lower prevalence of myopia $(29.4 \%)$ and high myopia $(0.4 \%)$ than those in Chinese urban cities, suggesting that Chinese people may not have a genetic predisposition to myopia and that environmental factors may play a major role in the development of childhood myopia in Chinese children. ${ }^{32}$

In the present study, the association between parental myopia and childhood VIUC was strong (table 3). In grade 10 to 12 students, the ORs were 2.06, 1.85 and 3.17 for paternal myopia only, maternal myopia only and both parents having myopia, respectively. Although the possibility of heredity for VIUC was not excluded, families also share environments, and myopic parents are more likely to create myopigenic environments such as more intensive education or less time spent outdoors, increasing the myopia risk of their children. ${ }^{18}$ In a study on the gene-environment interaction in myopia, the prevalence of child myopia was only $9.9 \%$ in farmer families without parental myopia, but the prevalence among college students was similar between farmer families and other families, suggesting a leading role of environmental factors in the formation of myopia. ${ }^{10}$ In another study on high myopia across three different generations in Korea, results showed that the environmental portion of the phenotypic variance increased and the additive genetic portion decreased as South Korea became more urbanised. ${ }^{33}$ Therefore, it remains to be established how geneenvironment interactions contribute to myopia within various populations. ${ }^{2}$

In the present study, we analysed the effects of perinatal factors, such as delivery manner, delivery mode and pregnancy diseases, on the prevalence of myopia. Pregnancy diseases, such as hyperemesis, hypertension, preeclampsia and uterus-related complications may affect fetal growth in the uterus and probably later long-term health. For instance, diabetes during pregnancy is associated with changes in retinal morphology in the offspring. ${ }^{34}$ We found that pregnancy diseases decrease the prevalence of childhood VIUC, and this relationship may be causal (table 2). Children whose mothers suffered from pregnancy diseases may have lower educational pressure than those without diseases in the family.

Premature birth and low birth weight affect the general growth of the fetus, including eye development. A previous analysis determined that in children born prematurely, the development of myopia is mainly influenced by anterior segment components, whereas hyperopia was mainly attributed to short axial length. ${ }^{18}$ In a British birth cohort study, myopia was positively associated with low birth weight for gestational age, ${ }^{14}$ and in the Sydney Paediatric Eye Disease Study, vision impairment was independently associated with low birth weight. ${ }^{19}$ In the present study, the parents only reported whether the participants were born before, on or after their due date, and no further information on precise gestational age was obtained. Regretfully, we cannot analyse the association between premature birth and childhood vision impairment.
Accordingly, we used multiple logistic regression models to analyse only the population with normal birth weight and without pregnancy complications.

Breast feeding may influence the early growth of a baby. In a cross-sectional study of 527 Chinese primary school students aged 6 to 12 years, breast feeding was reported to be associated with a decreased risk of myopia, and breast feeding during the first 6 months of infancy was associated with higher hyperopic spherical equivalent refraction. ${ }^{23}$ Furthermore, breast feeding was associated with myopic refraction and was not related to axial length, and this association could exist in childhood. ${ }^{23}$ In a study of Singaporean preschoolers, results showed that breast feeding was associated with higher hyperopic spherical equivalent refraction. ${ }^{35}$ Our results support the idea that breast feeding decreases and formula feeding increases the risks for VIUC (table 3). The underlying mechanisms remain unclear, but physical development may be associated with eye development as well.

Postnatal factors, including environmental factors, play critical roles in the development of childhood myopia. ${ }^{4}$ In an analysis of time spent on outdoor activity and on near-vision work, children with little outdoor time and much near-vision work were two to three times more likely to be myopic compared with those performing little near-vision work and spending much time outdoors. ${ }^{18} \mathrm{In}$ the area of Beijing, China, greater axial elongation was associated with less time spent outdoors and with more time spent indoors. ${ }^{6}$ In Finland, a higher risk of myopia was mainly related to parents having myopia and less time spent on sports and outdoor activities in childhood. ${ }^{8}$ In the Netherlands, seven parameters were associated independently with faster axial length elongation, including the number of books read per week, time spent reading, no participation in sports and less time spent outdoors. ${ }^{36}$

Our present results clearly support the idea that homework time is positively associated and outdoor activity is negatively associated with the prevalence of myopia and VIUC in students of all grades (tables 2 and 3). Therefore, environmental factors should be the leading consideration to reduce the incidence of childhood myopia. Indeed, in a recent clinical trial among 6-year-old children in Guangzhou, the incidence of myopia significantly reduced over the 3 years after the addition of $40 \mathrm{~min}$ of outdoor activity to the daily curriculum, replacing usual activity. ${ }^{7}$ Therefore, such interventions could be the most effective strategy to decrease the prevalence of VIUC in Chinese cities.

Our results also show that female gender, older age and not having siblings are associated with an increased risk for myopia. Similarly, in a study including 27607 -year-old children and 2198 12-year-old children, higher intraocular pressure was associated with female gender, older age and higher body mass index, while younger age at the commencement of reading and being born with a caesarean section were also associated with higher intraocular pressure in adolescence. ${ }^{17}$ However, these factors may be largely linked with environmental factors, such as 
outdoor activity and near-vision work. For example, boys are more likely to do outdoor sports; as one ages, the educational pressure increases; children without siblings are more likely to have indoor activities and near-vision work; and overweight decreases the outdoor activity of children. Therefore, the observed correlation may be causal.

Additionally, our data showed that paternal smoking did not significantly increase the prevalence of VIUC (table 3), suggesting that indoor pollution might not provoke the development of myopia. In a study in Singapore, an inverse association was found between parental smoking and childhood myopia, ${ }^{37}$ and our data also indicated that a current smoking status of the father decreased the risk of VIUC (table 3). Moreover, Guangzhou has markedly reduced its atmospheric pollution during the past 10 years, but the prevalence of myopia has further increased. ${ }^{5}$ Therefore, environmental pollution does not seem to be a major risk factor for childhood myopia. It is notable that female smoking is rare in China, to such an extent that in this study $99.2 \%$ of the mothers never smoked. Therefore, maternal smoking may not be a significant factor for consideration.

In conclusion, the results of the present retrospective study, conducted using 253301 completed surveys in the Guangzhou area of Southern China, indicated that factors such as the female gender, high birth weight, formula feeding, not having siblings, higher levels of parents' education, parental myopia, much homework time and little outdoor activity are significantly associated with a higher risk of vision impairment. Conversely, being born before the due date, being overdue and outdoor activity were associated with a decreased risk of vision impairment. Therefore, we here confirm known major prenatal/genetic, perinatal and postnatal factors for childhood VIUC. Although selection bias, recall bias and reporter bias were unavoidable, as this is a retrospective, self-reported survey, based on the current data, we conclude that prenatal and perinatal factors can affect the onset of childhood VIUC, but parental myopia and postnatal factors are the main factors. Therefore, children whose parents have myopia should be considered as a high-risk population for childhood VIUC, and intervention by changing environmental factors such as outdoor activities should be conducted for effective prevention of VIUC.

\section{Author affiliations}

${ }^{1}$ BioResource Research Center, The Third Affiliated Hospital of Guangzhou Medical University, Guangzhou, China

${ }^{2}$ Key Laboratory for Major Obstetric Diseases of Guangdong Province, The Third Affiliated Hospital of Guangzhou Medical University, Guangzhou, China

${ }^{3}$ Health Promotion Centre for Primary and Secondary Schools of Guangzhou Municipality, Guangzhou, China

${ }^{4}$ Department of Obstetrics, The Third Affiliated Hospital of Guangzhou Medical University, Guangzhou, China
Acknowledgements We thank LetPub (www.letpub.com) for its linguistic assistance during the preparation of this manuscript.

Contributors Conceived and designed the research: Dunjun Chen. Collected the data: Nali Deng. Analysed the data: Juanjuan Chen, Wen Sun, Jingsi Chen and Lili Du. Wrote the paper: Bolan Yu and Lijuan Dai.

Funding This study was supported by the National Key R\&D Program of China (grant number 2016YFC1000303), the Guangzhou City Science and Technology Administration (grant number 201804020057) and foundation from Lin He's Academician Workstation of New Medicine and Clinical Translation at The Third Affiliated Hospital.

Competing interests None declared.

Patient and public involvement Patients and/or the public were not involved in the design, or conduct, or reporting, or dissemination plans of this research.

Patient consent for publication Not required.

Ethics approval The Institutional Review Board of The Third Affiliated Hospital of Guangzhou Medical University (2017(№.128)).

Provenance and peer review Not commissioned; externally peer reviewed.

Data availability statement Data are available upon reasonable request. Deidentified participant data are available upon reasonable request.

Open access This is an open access article distributed in accordance with the Creative Commons Attribution Non Commercial (CC BY-NC 4.0) license, which permits others to distribute, remix, adapt, build upon this work non-commercially, and license their derivative works on different terms, provided the original work is properly cited, appropriate credit is given, any changes made indicated, and the use is non-commercial. See: http://creativecommons.org/licenses/by-nc/4.0/.

ORCID iD

Bolan Yu http://orcid.org/0000-0002-4498-8976

\section{REFERENCES}

1 GD W, Zhang CL. The impact factors of low visual acuity in Chinese teenagers (in Chinese). J Med Theor \&Prac 2005;18:29-31.

2 Morgan IG, Ohno-Matsui K, Saw S-M. Myopia. Lancet 2012;379:1739-48.

3 Resnikoff S, Pascolini D, Mariotti SP, et al. Global magnitude of visual impairment caused by uncorrected refractive errors in 2004. Bull World Health Organ 2008;86:63-70.

4 Pan C-W, Ramamurthy D, Saw S-M. Worldwide prevalence and risk factors for myopia. Ophthal Physl Opt 2012;32:3-16.

5 Rose KA, French AN, Morgan IG. Environmental factors and myopia: paradoxes and prospects for prevention. Asia Pac J Ophthalmol 2016;5:403-10.

6 Guo Y, Liu LJ, Tang P, et al. Outdoor activity and myopia progression in 4-year follow-up of Chinese primary school children: the Beijing children eye study. PLoS One 2017;12:e0175921.

$7 \mathrm{He} \mathrm{M}$, Xiang F, Zeng Y, et al. Effect of time spent outdoors at school on the development of myopia among children in China: a randomized clinical trial. JAMA 2015;314:1142-8.

8 Pärssinen O, Kauppinen M, Viljanen A. The progression of myopia from its onset at age 8-12 to adulthood and the influence of heredity and external factors on myopic progression. A 23-year follow-up study. Acta Ophthalmol 2014;92:730-9.

9 Ramamurthy D, Lin Chua SY, Saw S-M. A review of environmental risk factors for myopia during early life, childhood and adolescence. Clin Exp Optom 2015;98:497-506.

10 Wenbo L, Congxia B, Hui L. Genetic and environmental-genetic interaction rules for the myopia based on a family exposed to risk from a myopic environment. Gene 2017;626:305-8.

11 Sun W, Huang L, Xu Y, et al. Exome sequencing on 298 probands with early-onset high myopia: approximately One-Fourth show potential pathogenic mutations in RetNet genes. Invest Ophthalmol Vis Sci 2015;56:8365-72.

12 Gordon-Shaag A, Millodot M, Shneor E, et al. The genetic and environmental factors for keratoconus. Biomed Res Int 2015;2015:1-19.

13 Gillman MW. Developmental origins of health and disease. N Engl J Med 2005;353:1848-50.

14 Rahi JS, Cumberland PM, Peckham CS. Myopia over the lifecourse: prevalence and early life influences in the 1958 British birth cohort. Ophthalmology 2011;118:797-804. 
15 Williams KM, Kraphol E, Yonova-Doing E, et al. Early life factors for myopia in the British twins early development study. $\mathrm{Br} \mathrm{J}$ Ophthalmol 2019;103:1078-84

16 Čiumbaraitè R, Liutkevičienė R. Refractive errors characteristic of the patients at the children's ophthalmology outpatient department of Kauno klinikos Hospital (Lithuanian University of health sciences) from 1 January 2012 to 31 December 2012. Acta Med Litu 2017;24:83-92.

17 Li S, Li S-M, Wang X-L, et al. Distribution and associations of intraocular pressure in 7- and 12-year-old Chinese children: the Anyang childhood eye study. PLoS One 2017;12:e0181922.

18 Chen T-C, Tsai T-H, Shih Y-F, et al. Long-Term evaluation of refractive status and optical components in eyes of children born prematurely. Invest Ophthalmol Vis Sci 2010;51:6140-8.

19 Pai AS-I, Wang JJ, Samarawickrama C, et al. Prevalence and risk factors for visual impairment in preschool children the Sydney paediatric eye disease study. Ophthalmology 2011;118:1495-500.

20 Zhu X, Zhao R, Wang Y, et al. Refractive state and optical compositions of preterm children with and without retinopathy of prematurity in the first 6 years of life. Medicine 2017;96:e8565.

21 Ouyang L-J, Yin Z-Q, Ke N, et al. Refractive status and optical components of premature babies with or without retinopathy of prematurity at 3-4 years old. Int J Clin Exp Med 2015;8:11854-61.

22 Bhatti S, Paysse EA, Weikert MP, et al. Evaluation of structural contributors in myopic eyes of preterm and full-term children. Graefes Arch Clin Exp Ophthalmol 2016;254:957-62.

23 Liu S, Ye S, Wang Q, et al. Breastfeeding and myopia: a crosssectional study of children aged 6-12 years in Tianjin, China. Sci Rep 2018;8:10025

24 Yao YM, Li F L. Forecast on the size and structure trends of the onlychildren under the new birth policy (in Chinese). Journal of Zhejiang University 2015;45:94-104.

$25 \mathrm{MaX}$, Zhou Z, Yi H, et al. Effect of providing free glasses on children's educational outcomes in China: cluster randomized controlled trial. BMJ 2014;349:g5740.
26 Zeng Y, Han X, Wang D, et al. Effect of a complex intervention to improve post-vision screening referral compliance among pre-school children in China: a cluster randomized clinical trial. EClinicalMedicine 2020;19:100258.

27 Yang Y, Nan Y, MW T, et al. Major finding of 2015 China adults tobacco survery (in Chinese). Chinese Journal of Health Manage 2016;10:85-7.

28 Wu P-C, Huang H-M, Yu H-J, et al. Epidemiology of myopia. Asia Pac J Ophthalmol 2016;5:386-93.

29 Bernsen RMD, de Jongste JC, Koes BW, et al. Perinatal characteristics and obstetric complications as risk factors for asthma, allergy and eczema at the age of 6 years. Clin Exp Allergy 2005;35:1135-40.

30 Brandão HV, Vieira GO, de Oliveira Vieira T, et al. Increased risk of allergic rhinitis among children delivered by cesarean section: a cross-sectional study nested in a birth cohort. BMC Pediatr 2016;16:57.

$31 \mathrm{He}$ M, Zeng J, Liu Y, et al. Refractive error and visual impairment in urban children in southern China. Invest Ophthalmol Vis Sci 2004;45:793-9.

32 Pan C-W, Wu R-K, Li J, et al. Low prevalence of myopia among school children in rural China. BMC Ophthalmol 2018;18:140.

33 Ahn H, Lyu IS, Rim TH. The influence of parental myopia on children's myopia in different generations of parent-offspring pairs in South Korea. Semin Ophthalmol 2018;33:419-28.

34 Tariq YM, Samarawickrama C, Li H, et al. Retinal thickness in the offspring of diabetic pregnancies. Am J Ophthalmol 2010;150:883-7.

35 Sham WK, Dirani M, Chong YS, et al. Breastfeeding and association with refractive error in young Singapore Chinese children. Eye 2010;24:875-80.

36 Tideman JWL, Polling JR, Jaddoe VWV, et al. Environmental risk factors can reduce axial length elongation and myopia incidence in 6- to 9-year-old children. Ophthalmology 2019;126:127-36.

37 lyer JV, Low WCJ, Dirani M, et al. Parental smoking and childhood refractive error: the stars study. Eye 2012;26:1324-8. 